\title{
Using MI- Based Activities for Developing EFL Speaking Skills and Self- Efficacy of Preparatory Stage Visually- Impaired Pupils
}

\author{
A Research Paper \\ BY \\ Samah Rizk Ramadan Hassan \\ Lecturer, Curriculum\& Instruction Dept. (TEFL) \\ Faculty of Education, Mansoura University
}




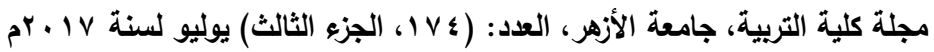

Using MI- Based Activities for Developing EFL Speaking Skills and Self- Efficacy of Preparatory Stage Visually- Impaired Pupils

\begin{abstract}
:
This study aimed at investigating the effectiveness of using multiple intelligences (MI) based activities in developing EFL speaking skills and self- efficacy for preparatory stage visuallyimpaired pupils at Al-Nour schools in Mansoura. Based on the literature review, related studies and content specification of first year prep, five EFL speaking sub-skills were determined. Instruments of the study included: an MI checklist for determining the most common intelligences among the VI pupils, a speaking test, and a self-efficacy scale for measuring those pupils' self-efficacy level before and after the experiment. The content of the units with MI-based activities was taught to pupils throughout twelve sessions. Results revealed that MI- based activities had a great effect on enhancing the students' EFL speaking skills and self-efficacy as there were statistically significant differences between each of the pre- and postadministrations of both the speaking test and self-efficacy scale. The study also proposed some recommendations and suggestions for further research.
\end{abstract}

Key Words: Multiple Intelligences, EFL Speaking skills, SelfEfficacy, the Visually-Impaired.

\title{
Introduction:
}

Learning a foreign language is important for everybody, particularly if the person's native language is not very widespread, and it is a demand for communication in modern world, including the use of the world wide web. It is now widely accepted that the study of a foreign language is an important pillar in the education of students, providing both practical and professional benefits, as well as to the realization of a more comprehensive education. Additionally, the students themselves choose to learn a foreign language on their own, motivated by the chances for a more flexible professional mobility and increased opportunities for tourism, entertainment, and communication (Christidou, 2016).

Language learning is even more important for visually impaired (VI) persons, in order to decrease the gap caused by sight loss or by severe visual impairment. Visual impairment affects every domain of human life, both on the personal level and the social one; including communication, mobility and human 
relationships. This is still more true in our society which is dominated by image and speed. Mastering a foreign language, particularly English, thus becomes a sort of "bridge" by means of which the visually impaired person can access different cultures and different prospects in the field of social contacts. In the case of the visually impaired person, words are of a much greater importance than for sighted people, because speech is the only means of communication available for constituting social relationships. Body language, movies, communication with images, all have to be translated into spoken or written words in order to be perceived also by the visually impaired (Shoeir, 2009; Quatraro, 2011).

Unfortunately, it is assumed that blind and visually impaired foreign language learners experience more difficulties in their foreign language learning than sighted learners as they need adaptive and technical accommodations in their learning process. More importantly, their opportunities for implicit foreign language learning are more limited. There are several obstacles connected with the absence of visual information and a necessity for adapted study and testing materials (Lovi, 2013).

Of all the four language skills, speaking seems subconsciously the most important: people who know a language are referred to as "speakers" of that language; as if speaking included all other dimensions of language mastery; and many if not most foreign language learners are primarily concerned with learning to speak the language first (Ur, 2009). Furthermore, speaking is an interactive process of forming meaning that includes, receiving, processing, and producing information (Brown, 1994; Burns\& Joyce, 1997). Speaking is of great importance for human beings as it is a fundamental means for communication and self-expression. With special reference to the visually impaired, speaking -or oral communication- is a major means of communication as it is easier, more direct and more expressive for them than written communication.

Unfortunately, speaking has occupied a peculiar position throughout the history of EFL teaching; it has begun to emerge as a branch of teaching and learning in the last two decades, and it rarely focuses on the spoken discourse (Bygate, 2002). With specific reference to the visually impaired situation, dictations, drillings, class discussions and sometimes role plays are the most common strategies in teaching in general (Habibi\& Jamila, 2014).

According to Albert Bandura, self-efficacy refers to how individuals perceive their capabilities to perform certain tasks. Therefore, students who feel confident in relation to a certain task will perform better, consequently taking on even more challenging

$$
-\Lambda \cdot \Lambda-
$$




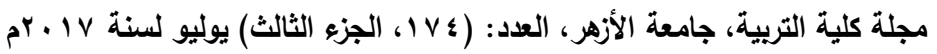

tasks. This confidence (self-efficacy) has a profound impact on the future personal and intellectual success of all students, and conversely when their intellectual needs are not being met, students will generally not have a high sense of self-efficacy (Cubukcu, 2008).

Among new trends in EFL instruction and in education in general, appears the theory of multiple intelligences. Gardner- the founder of that theory- believed that all human beings have a mixture of eight types of intelligences which work together to make them different and unique individuals (Richards\& Rodgers, 2001; Hajhashemi, Akef\& Anderson, 2012). The intelligence types developed by Gardner are: verbal-linguistic, logicalmathematical, visual-spatial, bodily-kinesthetic, musical, interpersonal, intrapersonal and natural intelligences. Language learning can be supported by evoking these various abilities as they constitute diverse frames for working on the same linguistic content. This variety of presentations allow students to learn in their own best ways. In addition, it also helps to reduce monotony as language learning requires frequent circling back over the same material if learning is to be persistent (Arnold \& Fonseca, 2004).

\section{Context of the problem:}

The VI pupils study the same curriculum presented to their sighted peers with only some adaptations like deleting pictures, some guessing exercises and drillings. The deleted parts are substituted with lists of words out of their natural context, and pupils are asked to memorize these lists as they are, which ultimately leads to verbalism. In addition, the teacher's guide is directed only to teachers of the sighted; no advice is given to teachers of the VI on the methodology and teaching aids appropriate to this category of pupils in order to facilitate learning English and practicing its skills. Finally, most teachers use lecturing techniques almost all the time. They barely engage pupils in learning strategies that address their potential capabilities or intelligences. They think that vision loss prescribes dictating pupils answers for expected questions in exams to memorize them only (Mohamed, 2004; Shoeir, 2009; Quatraro, 2011; Başaran, 2012; Abdelhady, 2014).

In spite of the prominence of developing EFL speaking skill, it can be declared that teaching speaking at Al Nour schools for the VI has been restricted to loud reading of dialogues and just question and answer activities. Furthermore, the evaluation system adopted in Egyptian EFL education in general focuses only on reading and writing while neglecting listening and speaking skills. Deprived from using visual prompts as well as the 
surrounding environment, the VI pupils are also deprived from having meaningful practice opportunities for developing their EFL speaking skills. Thus, VI pupils lack essential EFL speaking skills; a window that should be wide open for them to express themselves orally.

In addition, this problem was further substantiated by informal interviews conducted by the researcher with the English language teachers at AI Nour schools for the VI in Mansoura City. During these interviews, teachers were asked certain questions, such as: "How do you teach EFL speaking skill? What are some activities that you use to develop speaking? Have you tried before to assess your students' intelligences? Have you ever tried to implement MI- based activities in your classes?". Results of these informal interviews showed that teachers suffer from very limited choices in their teaching; as their focus is mainly on teaching for passing the exams, and thus they exert tremendous efforts in dictating questions and their answers for the pupils to memorize. Consequently, chances of varied meaningful practice of speaking skills are rare. Furthermore, activities such as MI- based are not being even attempted in the classroom.

In addition to the informal interviews undertaken by the researcher with the EFL teachers at Al-Nour school for the VI pupils, the current research problem is determined after a set of clues has been inferred that can be explained as follows:

1. The visually impaired are not generally different from their sighted peers regarding their learning ability, as they can carry out all activities and tasks performed by sighted students using modified tools and materials commensurate with the nature of their visual impairment (Basaran, 2012).

2. Thinking about how to overcome the difficulties imposed by the visual impairment should be the basis of the educational philosophy of the visually impaired (Shoeir, 2009).

3. Gardner considers that anyone who is capable of developing his eight intelligences has a reasonable level of high performance if he is provided with encouragement, enrichment and appropriate teaching (Armstrong, 2000, p. 9)

4. The theory of multiple intelligences is not specifically related to the senses. A person may be blind and has spatial intelligence, or be deaf and at the same time has musical intelligence (Armstrong, 2000, p. 10).

5. The scarcity of studies and researches that dealt with using multiple intelligences- based activities in developing the speaking skill and self-efficacy of pupils with visual impairment at the preparatory stage. 
Thus, like their peers with regard to their multiple intelligences, the visually- impaired pupils need a variety of activities that suit the nature of their impairment and the quality of their multiple intelligences.

\section{Statement of the problem:}

The problem of the study can be identified in the poor performance of EFL speaking skills of VI pupils at the preparatory stage and their self-efficacy is remarkably low regarding their performance in speaking activities and in English lessons in general. Hence, the current study sought to find an answer to the following main question:

What is the effectiveness of using MI- based activities in improving EFL speaking skills and self-efficacy of visuallyimpaired pupils at preparatory stage?

The following sub-questions were sought to be answered:

1. What are the multiple intelligences (MIs) dominant among first year preparatory stage visually impaired pupils?

2. What are the features of a treatment based on multiple intelligences to develop first year preparatory stage VI pupils' EFL speaking skills and self-efficacy?

3. To what extent is using MI- based activities effective in developing first year preparatory stage VI pupils' speaking skills?

4. To what extent is using MI- based activities effective in developing first year preparatory stage VI pupils' selfefficacy?

\section{Hypotheses of the study:} hypotheses:

The current study attempted to verify the following

1. There is a statistically significant difference at (0.05) level between the mean ranks of the experimental group pupils' scores on the pre- and post- administrations of the speaking test in favor of the post- administration.

2. There is a statistically significant difference at $(0.05)$ level between the mean ranks of the experimental group pupils' scores on the pre- and post- administrations of the self-efficacy scale in favor of the post- administration. 


\section{Instruments of the study:}

The following instruments were designed and used in the present study:

1. Multiple Intelligences Checklist: to identify the most common types of intelligences among the pupils participating in the study (Armstrong, 2009, pp. 35-38. Adapted by the researcher).

2. A speaking test: to be used as a pre- and post-test for assessing the pupils' speaking skills before and after implementing the proposed MI- based activities with an accompanying rubric for scoring the test. (Prepared by the researcher)

3. A Speaking Self-efficacy Scale: to assess pupils' self-efficacy before and after implementing the proposed treatment. (Prepared by the researcher)

\section{Purpose of the study:}

The present study aimed at:

1. Proposing a framework for designing MI- based activities for visually- impaired pupils that considers the nature of their disability.

2. Determining the effectiveness of using MI- based activities in developing first year preparatory stage VI pupils' speaking skills.

3. Determining the effectiveness of using MI- based activities in developing first year preparatory stage VI pupils' self-efficacy.

\section{Significance of the study:}

It is hoped that the current study would contribute to:

1. Directing the attention of EFL curriculum planners towards the importance of integrating MI theory in EFL textbooks, especially for the VI pupils.

2. Raising the awareness of special education curriculum designers towards the necessity of adapting VI EFL textbooks to suite the visual impairment and exploit their remain senses and their multiple intelligences.

3. Helping EFL teachers of the VI to adapt their teaching practices to suit the needs of their pupils through implementing MI-based activities in their classes. 


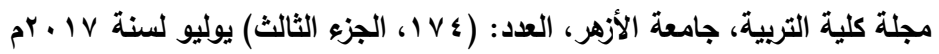

4. Helping the VI pupils to learn and develop their EFL speaking skills in such a way that matches their intelligences, and hence enhances their self-efficacy.

5. Attracting the attention of researchers in the field of EFL for special education in general and for VI pupils in particular; as this field is currently, although very important, still underresearched.

\section{Delimitations of the study:}

The current study was restricted to the following delimitations:

1. Units (1) "All about me" and (2) "My family at work" in New Hello! English for preparatory schools, Year One, first term.

2. A sample of first year preparatory stage visually- impaired pupils at Al-Noor School for the VI in Mansoura City, West Mansoura Educational Directorate.

\section{Definition of terms:}

\section{Multiple Intelligences:}

Gardner's (1983) theory presents different intelligence capacities that result in many different ways of knowing, understanding, and learning about the world. Gardner's MI theory states an alternative definition of intelligence based on a radically different view of the mind. It encompasses eight types of intelligences as follows: (Gardner, 1999, pp. 41-43).

1. Verbal/ Linguistic: "involves sensitivity to spoken and written language, the ability to learn languages, and the capacity to use language to accomplish certain goals. Lawyers, speakers, writers, poets are among the people with high linguistic intelligence".

2. Logical/ Mathematical: "involves the capacity to analyze problems logically, carry out mathematical operations, and investigate issues scientifically. Mathematicians, logicians, and scientists exploit logical-mathematical intelligence.".

3. Visual/ Spatial: "the potential to recognize and manipulate the patterns of wide space (those used, for instance, by navigators and pilots) as well as the patterns of more confined areas (such as those of importance to sculptors, surgeons, chess players, graphic artists, or architects)". It also involves sensitivity to color, line, shape, form, space, and the relationships that exist between these elements.

4. Bodily -Kinesthetic: "entails the potential of using one's whole body or parts of the body (like the hand or the mouth) to solve problems or fashion products". Obviously, it is represented 


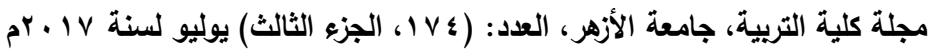

clearly in dancers, actors, hand- craft professionals and athletes.

5. Musical/ Rhythmic: "entails skill in the performance, composition, and appreciation of musical patterns". It can be seen in musicians, dance bands and composers.

6. Interpersonal: "a person's capacity to understand the intentions, motivations, and desires of other people and, consequently, to work effectively with others. Salespeople, teachers, clinicians, religious leaders, political leaders, and actors all need acute interpersonal intelligence". It includes the ability to work cooperatively with others in a group and to communicate verbally and nonverbally with others.

7. Intrapersonal: "the capacity to understand oneself, to have an effective working model of oneself-including one's own desires, fears, and capacities-and to use such information effectively in regulating one's own life".

8. Naturalistic: "designates the human ability to discriminate among living things (plants, animals) as well as sensitivity to other features of the natural world (clouds, rock configurations)"

Lately, Gardner (1999) proposed adding the existentialist intelligence to the previous list, however, it is rarely mentioned in educational literature.

Gardner (1983) views MI classroom activities as "a tool through which any content area can be conveyed to students by utilizing their different inner capacities, abilities or intelligences". Using this type of instruction integrates many of the students' intelligences as they are involved in various activities which are based on different types of intelligences.

\section{Visually-Impaired pupils:}

Visually- impaired pupils are "learners who have visual acuity of $6 / 60(20 / 200)$ or less in the better eye with correction. They have either no vision, or, at most, light perception". Such pupils receive the educational services at Al-Nour schools all over the Egyptian governorates. They learn through the use of Braille and other media that utilize the remaining senses.

According to Davis (2003), the term 'visual impairment' refers to "children who are classed as blind or as having low vision. The nature and degree of visual impairment may vary significantly, so each student may require individual adaptations to instructional practices and materials in order to learn effectively". On the other hand, Visual impairment refers to "the function of the eye and can be measured with tests such as visual acuity, visual field, color vision, and contrast sensitivity". 


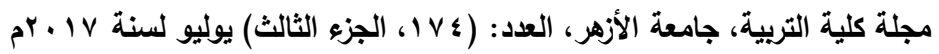

Division of visual impairments according to National Dissemination Centre for Children with Disabilities:

Partially sighted - the term refers to "a person with some type of visual difficulty which results in the need of special education".

Low vision - there is a severe visual impairment in a person. It does not necessarily have to be a distance vision problem. The term applies to all individuals who are unable to read a newspaper text common size at normal reading distance and this disability cannot be corrected by glasses or lenses. These people usually use another sense or possibly other senses to learn. Some of them may make use of additional lighting and / or text size change.

Legally blind - a person has less than 20 / 200 sight in the better eye (the first number indicates the length in meters needed by a visually impaired person to see an object and the second number indicates the length in metres needed by a non-visually impaired person to see the same object). This is often accompanied by a very limited vision field.

Totally blind - those people have to learn with the help of Braille print and other non-visual aids. Some of the people are able to recognise darkness and light, some of them do not perceive the difference at all.

Speaking skills:

Speaking is defined as "an interactive process of constructing meaning that involves producing, receiving and processing information. Its form and meaning are dependent on the context in which it occurs, the participants, and the purposes of speaking" (Burns \& Joyce, 1997).

According to Nunan (2003), speaking is "a productive oral skill that involves the production of a system of verbal utterances to send meaning". Furthermore, Rizvi (2006, p.92) defined speaking as "an interactive and communicative process that involves speakers and listeners. It is not only the oral production of written language, but the mastery of a wide range of sub-skills of learners as well."

Speaking is defined operationally in this study as the ability of visually-impaired first year prep stage pupils to express themselves orally, in a given meaningful context to serve both transactional and interactional purposes using correct pronunciation, grammar and vocabulary. In other words they are

${ }^{1}<$ http://nichcy.org/disability/specific/visualimpairment $>$ [23.2.2012] 


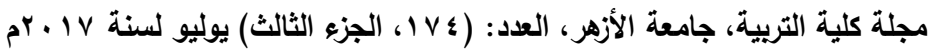

required to show mastery of the following sub- skills: Pronunciation, Accuracy/ Grammar, Vocabulary, Fluency, and Comprehensibility.

\section{Self-efficacy:}

In an early definition, Bandura (1994) proposed that perceived self-efficacy is defined as "people's beliefs about their capabilities to produce designated levels of performance that exercise influence over events that affect their lives". Therefore, self-efficacy beliefs determine how people feel, think, motivate themselves and behave.

Bandura (1997) defines self-efficacy as "beliefs in one's capabilities to organize and execute the courses of action required to produce given attainments" (p. 3).

Bandura has also defined self-efficacy $(1997$, p. 21) as "people's judgments of their capabilities to organize and execute courses of action required to attain designated types of performance". Thus, self-efficacy is one's belief in individual capacities and abilities of conducting a certain task rather than the real abilities the individual has.

In the current study, self-efficacy is operationally defined as: visually-impaired pupils' beliefs in their capabilities to organize and execute MI- based speaking activities in English classes.

\section{Review of literature:}

The following section sheds more light on the main variables of the current study which are the speaking skill, visually-impaired pupils, the MI theory and its based activities, and self-efficacy.

\section{Speaking skill:}

Speaking as a productive skill is a complex activity. It encompasses various aspects to be considered in teaching; such as accuracy of grammar, choice of vocabulary and clear pronunciation. Speaking skill does not mean just producing the utterances, but it is the complete process of constructing meanings, producing utterances and receiving and processing information (Brown, 1994). Moreover, Shumin (2002) illustrated that speaking a language is especially difficult for foreign language learners because effective oral communication necessitates the ability to use the language appropriately in social interaction. As a result, EFL learners, with lack of exposure to the target language, are relatively poor at spoken English. They cannot think of the exact words/sentences in speaking. Further, 


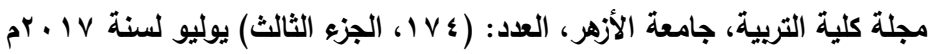

unlike reading or writing, speaking happens in real time, so they cannot edit or revise what they want to say (Bailey in Nunan: 2003:47).

Concerning functions of speaking, Richards and Renandya (2002) and Richards (2008: 21-28) proposed a three-part version of talks: interaction, transaction, and performance. Each of the three is different in form and function and requires different teaching approaches. First of all, talk as interaction refers to "conversation" and focuses on speakers and how they wish to present themselves to each other than on the message. It does not focus on the accuracy and clarity of the information; yet it is "listener-oriented." The varieties of talk as interaction include joking, small talk, chatting, opening and closing casual conversations. Second, talk as transaction refers to situations where the focus is on what is said and done. It is messageoriented, thus clarity and accuracy of the topic, effective and meaningful transfer of information are the principal focus. Such type includes making a telephone call, class discussions, ordering a meal, booking a room in a hotel, , and problem solving activities in general.

Finally, talk as performance, according to Richards (2008: 27), refers to public talk that transmits information before an audience such as speeches, presentations, and public announcements. This kind of talk is characterized by its generic structure and predictable organization and sequencing. Performance focuses on both listener/audience and message. Moreover, form and accuracy at the same time are considered important. It is closer to written than oral communication, as it usually prepared in advance.

The Language learners use language in their daily lives to different extents mainly to achieve communicative purposes. Unfortunately, oral communication skills are viewed as the most difficult to be developed (Brown, 1994). Therefore, EFL learners need explicit instruction in speaking, which, like any language skill, generally must be learned and practiced. However, in practice, teachers do not have much time to concentrate on the speaking skill, and it is too often assumed that it can be developed simply by assigning students general topics to discuss or by getting them to talk on certain subjects (Shumin, 2002). Using alternative teaching strategies depending on brain-based instruction as well as addressing various abilities and intelligences may help develop speaking skills (Salem, 2013).

Various approaches had been attempted for developing speaking skills. Communicative activities such as discussions, problem- solving, role- plays proved to be effective in developing 


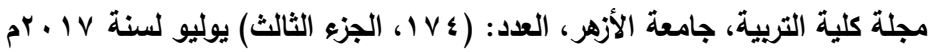

speaking skills (Tumova, 2002; Oradee, 2012). Creative dramatics, storytelling and literature are other creative approaches that proved effective in developing speaking skills (Mohammed, 2004; Ainy, 2007). Task- based approach was a major approach in developing speaking skills as it suites the transactional and interactive purposes of speaking (Torky, 2006; Boonkit, 2010). Multimedia programs were other venue for developing speaking skills and proved effective as well (Diyyab, 2013; Farag, 2015). Multiple Intelligences is a contemporary venue for improving language skills in general, and speaking skills in particular. It will be discussed later in MI section of this review.

The visually- impaired:

The term visual impairment refers to "the function of the eye that can be measured with tests such as visual acuity, visual field, color vision, and contrast sensitivity" (Davis, 2003). It covers deficiencies ranging from partial sight to blindness. An individual who is virtually handicapped, her/his ability to see is affected, hindered, or completely lacking. This shortcoming has a serious implication for the learning event, personal development, and progress towards self-actualization. The partially sighted are those who can read bodies of large print and who need magnifying devices. A partial sighted person has sufficient functional visual efficiency in such measure that vision rather than touch or hearing can be utilized as a chief avenue of learning. These visually impaired students, more often than not need a lot of support in academic institutions (Mushome \& Monobe, 2013).

The way the visually impaired perceive the world and classroom activities are believed to be quite different from those without any impairment. Therefore, techniques that are used to educate the visually impaired in general and teaching them English in particular and theoretical assumptions underlying such teaching or instruction are supposed to be rather different (Başaran, 2012). However, Hallahan and Kauffman (1991) agreed that visually impaired students should be educated in the same general way as sighted children. The main difference is that visually impaired students will have to rely on other sensory modalities to acquire information.

The constant challenges that face teachers of the VI include that students should have equal access to books and material choices as their sighted peers, the specialized equipment for VI students is very expensive or time-consuming, teachers should first exhaust the simple possibilities for material production or acquisition and make use of their own strengths and simple materials, rather than wait to obtain specialized materials, and even the basic teaching materials for visually impaired are hard to 


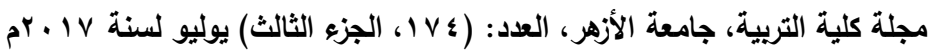

find, create or use and teachers are less knowledgeable about materials addressing the needs of visually impaired students (Efstathiou \& Polichronopoulou, 2015).

Speaking and listening skills are of great prominence to pupils with visual impairment, as the world is not all the time full of accessible text. In some situations, it may be more appropriate for pupils with visual impairment to listen rather than read, or to speak rather than write. They are challenged to depend on effectiveness in using a language in a world that is becoming increasingly visual. Thus, it is a must that they should be encouraged to develop their communication and language skills to their full potential (Salisbury, 2008; Habibi \& Jamila, 2014). However, in spite of having verbal language through which they communicate with others, express themselves, and adapt with their society, they miss the non-verbal dimension of language, such as signals, looks, facial expressions and lip movement. Therefore, teachers must be able to utilize effective strategies for developing communication skills of visually impaired pupils (Shoeir, 2009).

It is generally accepted by most teachers that in teaching EFL to the visually impaired pupils, for the transmission of the meaning of foreign words, they use their mother tongue more than they would like to. Another approach to teaching supports the use of physical expression to help speak in the foreign language. Role plays and dramatized dialogues not only help students to develop orientation and mobility skills, but also help them put to use the language of a particular meaning and practice linguistic expressions. An active and multisensory approach is encouraged in this way. Finally, another feature that enhances the motivation of the students and supports understanding by giving meaning to learning is to negotiate the content of learning. This will inevitably be done in the students' mother tongue and since in this way students fully understand what they are learning, the advantages outweigh by far the disadvantages of the use of the mother tongue (Christidou, 2016).

The choice of activities which can be employed in a lesson with visually impaired are limited, but teachers should not be discouraged by this fact. On the contrary, it gives them the opportunity to be creative. There are some activities which cannot be used under any circumstances; mostly those which are somehow connected to vision, although some activities, such as using a video, can be used, but must be modified as the teacher has to describe the scene to the student while watching it. Activities which are impossible to be used are e.g. describing pictures, describing the surroundings or the classmates, spot the difference (based on pictures), retelling a story based on pictures, 


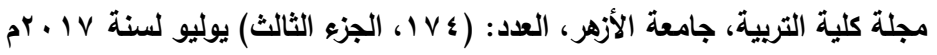

any activity connected based on drawing, watching a video without the sound etc. (Galetová, 2012).

meeting

Learning takes place best when it can be individualized,

particular needs and interests of each student. Therefore, every educator should assess their VI pupils' multiple intelligences to address their strengths and build upon their weakness. According to Gardner, "the broad spectrum of student and perhaps the society as a whole-would be better served if disciplines could be presented in a number of ways and learning could be accessed through a variety of means" (Priyadarshini, 2015).

Despite the developing body of research studies and projects related to English language teaching (ELT) for the ordinary learner, there is still a great shortage of research addressing the foreign language learning needs of the visually impaired learners (Coşkun, 2013). Few studies have investigated the effectiveness of proposed approaches in the field of language instruction for the visually impaired. Kashdan et al. (2002) for example, indicated that a "holistic communicative perspective" incorporating multisensory and multiple intelligence is fundamental for VI learners to learn a new foreign language. Mohamed (2004) proved the effectiveness of cooperative learning in developing English vocabulary learning for VI pupils at the primary stage. Another attempt was done by Millian and Pearson (2005) who proposed the dual-language education for VI learners; a method used in USA aiming to teach English speakers and nonEnglish speakers to learn a second language together.

The role of assistive technologies in language learning was excessively explored later. Coşkun (2013) investigated an innovative method, talking tactile technology (T3), which is a touch sensitive device providing immediate auditory feedback that teachers were eager to use. Many CALL projects and applications were developed for developing FL skills of the VI learners. For example, ALLVIP Project (Accessible Language Learning for VI People) (Stein et al. (2011), An English Eye (Jayakody et al., 2016) and ELLVIS (English Language Learning Program for VI Students) (2009-2011) and other projects. However, these projects are limited to and available for certain populations. Limited resources in Egyptian classrooms may be an obstacle for integrating assistive technology.

To conclude, all the studies conducted in FL education of VI yielded common results which revealed that VI students can learn a foreign language like their sighted peers, if they are provided with adequate teaching methods and strategies. Vision 


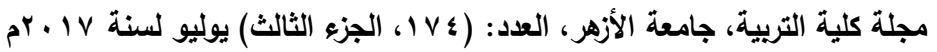

loss is not a barrier for the FL education of the VI, yet environmental challenges affect their learning process.

\section{Self-efficacy:}

The affective side of EFL learners is probably one of the most important factors that affects language learning success or failure. The affective factors relate to second or foreign language learning are emotions, self-esteem, empathy, anxiety, attitude and motivation. Second or foreign language learning is a complex task that is vulnerable to human anxiety, which is associated with feelings of uneasiness, apprehension, self- doubt, and frustration (Shumin, 2002).

Speaking a foreign language in public is often anxietyprovoking. It is a productive skill that challenges students' capability to perform a task. The key to communication is the ability to communicate or speak with other people; so it is mostly carried out in a real-time which demands learner's abilities to plan, process and produce the language. This poses a difficult task for students attempting to master speaking skills, especially EFL learners (Khatib\& Marouf, 2015). one of the most important factors to control students in speaking English is their belief and confidence on their capability, or the so called self-efficacy.

As the matter of that, self-efficacy, is a term used to refer to a person's belief concerning his or her ability to complete a task and perceived competency level with performing the task. According to Bandura, self-efficacy beliefs serve as a key motivational force in cognitive system and considered to be a central mediator of effort. Consequently, the beliefs that students have about their ability to speak can either encourage or make them hesitate to speak English in front of others in the classroom.

In short, having the knowledge and skill needed in a language learning task does not always guarantee that a student will succeed proficiently to perform it. It is because self-efficacy affects individual's behavior in four ways: selecting choice of behavior, determining how much and how long of the effort, affecting an individual's thought patterns and emotional reaction, and recognizing human as producers than foreteller (Pajares, 2000). For example, a student with low self-efficacy creates fear and doubt that bring him away to track his learning goals; then he thinks that activities are more difficult than they really are; this develops stress and failure on learning. Moreover, self-efficacy can affect motivation and choice of activities. A student with high self-efficacy will give great effort when facing difficulties, while a student who has low self-efficacy may doubt his ability (Cubukcu, 2008). 


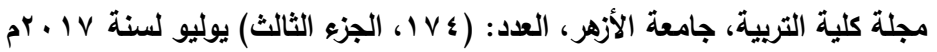

Meanwhile, Zimmerman (2000: 82- 91) added that selfefficacy "focuses on performance capabilities than personal qualities, such as physical or psychological characteristics". To support what Bandura initiated, Cubukcu (2008) summarizes that self-efficacy beliefs are affected more by one's own direct experiences with tasks than social comparison. In self-efficacy, students do not compare their perceived competence with their peers' ability in the same area. They assess themselves of how capable they are to accomplish a given task.

Concerning the issue that students with higher degrees of self-efficacy exert greater effort in order to perform the required tasks (Pajares, 2000), many researchers investigated the relationship between self-efficacy and language skills achievement in the field of English language teaching. For example, both Chen (2007), and Rahimi and Äbedini (2009) proved a positive correlation between self-efficacy and listening proficiency. In relation to writing skill, Pajares \& Johnson (1996), Pajares and Valiante (1997) and Hosseini Fatemi and Vahidnia (2013) examined writing self-efficacy beliefs and proved that self-efficacy was a central predictor of students' writing performance. Further, Chea and Shumow (2014) declared that both writing self-efficacy and writing mastery goal orientation were shown to have positive correlations with writing achievement.

Similarly, some studies such as Shang (2011), Naseri\& Zaferanieh (2012), Yogurtcu (2013), Kargar\& Zamanian (2014) and Hedges and Gable (2016) revealed a positive relationship between self- efficacy beliefs and reading comprehension skills achievement. As for the speaking skill, Liu (2013) indicated a positive correlation between college students' speaking selfefficacy and their speaking performance. Finally, Asakereh and Dehghannezhad (2015) revealed that speaking self-efficacy beliefs was a significantly strong predictor of Iranian EFL students' speaking skills achievement.

\section{Multiple Intelligences:}

Howard Gardner's MI theory $(1983,1999)$ is an important contribution to cognitive science and constitutes a learner-based philosophy which is "an increasingly popular approach to characterizing the ways in which learners are unique and to developing instruction to respond to this uniqueness" (Richards \& Rodgers, 2001: 123). The concept of intelligence began to lose its ambiguity and became a functional concept that could be seen working in people's lives in a variety of ways (Armstrong, 2009).

According to Gardner (1999), all human beings possess all different intelligences in varying degrees and each individual 
demonstrates varying levels of these different intelligences and thus each person has a unique "cognitive profile"; that is, a) all human possess all different intelligences in varying amounts; b) Each individual has a different composition; c) Different intelligences are located in different areas of the brain and can either work independently or together; d) By applying Multiple Intelligences we can improve education; and e) These intelligences may define human species (Razmjoo, 2008).

Furthermore, the Multiple Intelligences Theory (MIT) provided evidence that there are several independent ability areas, unlike traditional general intelligence concentrating on a narrow range of two logical-mathematical and linguistic intelligences. Gardner redefined the concept of intelligence as a "biopsychological potential to process information that can be activated in a cultural setting to solve problems or create products that are of value in a culture" (Gardner, 1999, pp. 33-34).

Multiple intelligences consist of three domains: the analytical, introspective and interactive domains. These three domains serve as an organizer for understanding the fluid relationship of the intelligences and how the intelligences work with one another (McKenzie, 2002; Razmjoo, 2008; Derakhshan \& Faribi, 2015). Figure (1) represents the three domains. 


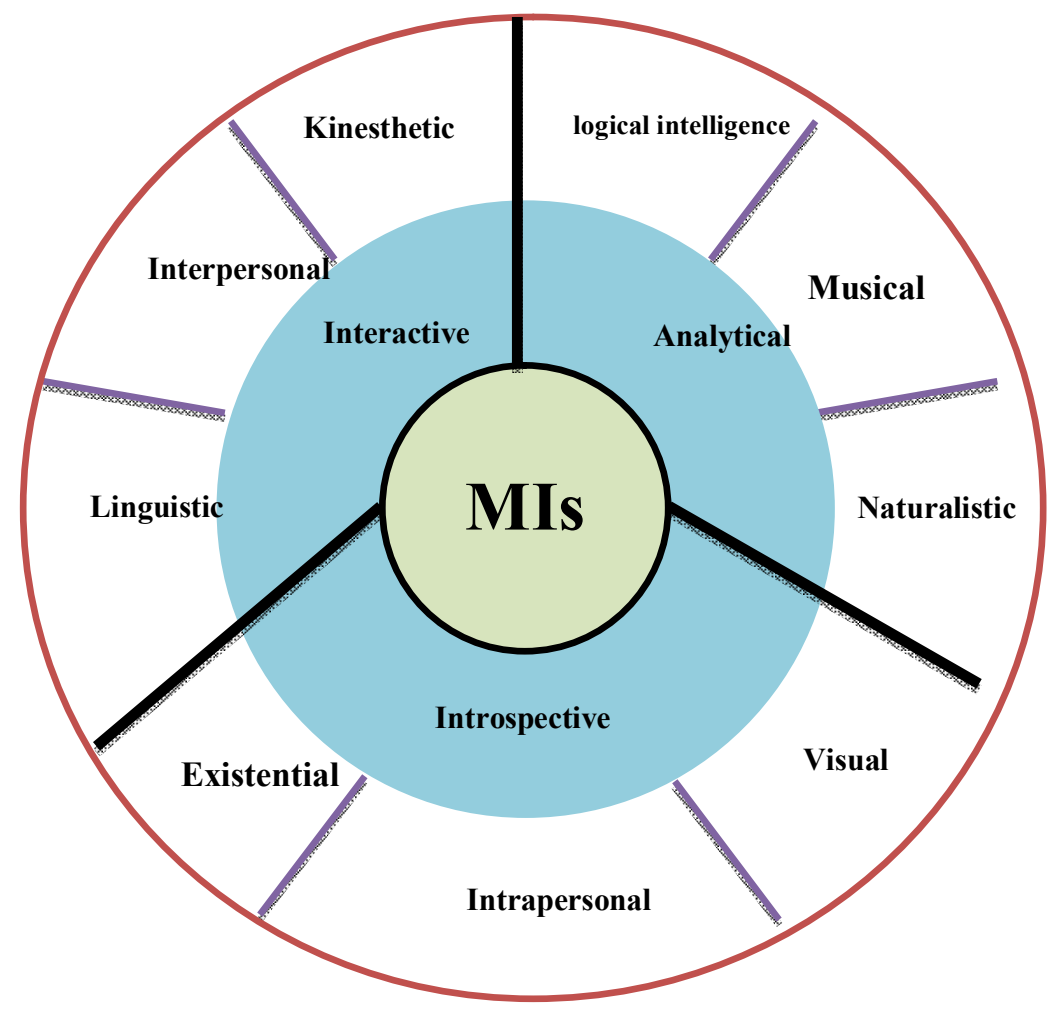

Figure (1): Multiple Intelligences Domains 


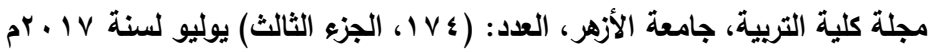

According to McKenzie (2002), the analytic domain consists of the logical, musical and naturalist intelligences. These are the intelligences concerned with stimulating analysis of knowledge that is presented to the learner. Second, the interactive domain consists of the linguistic, interpersonal and kinesthetic intelligences. These are the intelligences employed by learners to express themselves and explore their environment through encouraging interaction to achieve understanding. Third, the introspective domain consists of existential, intrapersonal, and visual intelligences. These are the intelligences that have a distinctly affective component as they require learners to have an internal meditation, an emotive connection to their own experiences and beliefs in order to make sense of new learning to them.

In Gardner's view, it is of vital importance to recognize and develop all of these varied human intelligences; they are of neutral value; none of them is considered superior to the others and they represent a full display of learners' individual differences. They are understood as tools that every learner possesses to make sense out of new information which can be stored for later use (Zhu, 2011). In addition, each of these frames is autonomous, changeable and trainable (Armstrong, 2000) and they interact to facilitate the solution of daily problems.

Christison (1999) identified four ways in which the MI theory can be used in the classroom. It can be used as a tool to help students develop a better understanding and appreciation of their own strengths and their learning styles, to develop a better understanding of learners' intelligences, as a guide to provide a greater variety of ways for students to learn and to demonstrate their learning, and as a guide to develop lesson plans that address the full range of learners' needs.

Concerning special education, MI theory has broad implications. By focusing on a wide spectrum of abilities, MI theory places "disabilities" in a broader context of being whole persons possessing strengths in many intelligence areas. It provides a growth paradigm for assisting special-needs students in school. It acknowledges difficulties or disabilities but does so within the context of regarding special-needs students as basically healthy, and suggests that "learning disabilities," for example, may occur in all eight intelligences (Armstrong, 2009). With special reference to the visually impaired pupils, it is recommended that in order to succeed in English language learning, teachers should promote Gardner's Multiple Intelligences' theory, because it proposes a multi-sensory aspect of learning (Kashdan, Barnes\& Walsh, 2002). 


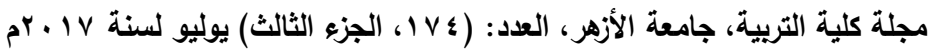

By constructing a perspective of special-needs students as whole individuals, MI theory provides a context for conceptualizing positive passages through which students can learn to adapt with their disabilities. Educators who view disabilities in the light of the eight intelligences perceive that disabilities occur in only part of a student's life; thus, they can begin to focus more attention on the strengths of special-needs students as a prerequisite to initiate a successful learning experiences (Armstrong, 2009); the prominent premise of MI theory.

Gardner (1983) views MI classroom activities as "a tool through which any content area can be conveyed to students by utilizing their different inner capacities, abilities or intelligences". Using this type of instruction addresses many of the students; intelligences as students are involved in various activities which are based on different types of intelligences. Further, the greatest effect of the theory in the process of teaching is to increase the creativity of teachers in developing teaching strategies that consider variety among learners. When teachers and planners think of activities for each intelligence type, they inevitably enlarge their method and technique repertoire, create distinguished and original techniques. All in all, MIT is an excellent tool to enable teachers to plan attractive ways to provide learners with language learning practice (Arnold \& Fonseca, 2004; Derakhshan \& Faribi, 2015).

Studies that handle applying MI theory in the field of language instruction are numerous. Grow (1990) maintained that employing MI theory in writing classrooms would allow for some innovative ideas and would add theoretical depth to pedagogical practices. Similarly, Marefat (2007) investigated the possible relationship between the students' MI profile and their writing product, and found kinesthetic, existential and interpersonal intelligence types to be most useful for predicting students' writing scores. El-Embaby (2008) reported that MI activities were effective in developing students' writing competencies. Furthermore, Eng and Mustapha (2010) found that incorporating MI theory into writing classrooms would positively contribute to the student's overall writing ability.

Aiming at establishing a link between the students' MIs and their reading skill, McMahon, Rose and Parks (2004) found logical-mathematical intelligence as a predictor of reading achievement. More recently, Rayyes (2011) proved the effectiveness of MI activities in improving the reading skills in an English course given for the female students of the first intermediate grade. The results of Modirkhamene and Azhiri's (2012) study crystallized the effects of MI-based reading tasks on 


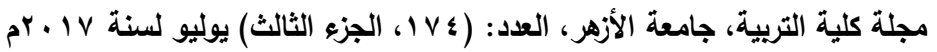

both EFL male and female learners' reading comprehension. Finally, Gullatt (2008) proposed that by involving students in learning that satisfies their specific intelligence strengths, they will become more active participants in the learning process.

Some studies explored the effectiveness of using MI activities in developing EFL speaking skills. Ibrahim (2007) explored the impacts of using a proposed strategy based on MIT in assessing and developing the oral skills. The sample of the study was third year primary school Arabic native speakers students. Results showed the usefulness of the training program based on MIT. Additionally, Dorgham (2011) investigated the effectiveness of using MI based instruction on developing speaking skills of the preparatory schools first graders. The program proved the usefulness of MI based instruction on developing first year preparatory stage students' speaking skills.

Considering the link between MIs and EFL self-efficacy, Shore (2001, cited in Al-Faoury\& Smadi, 2015) conducted a study to examine the use of MIs in the university EFL classroom. Results revealed that highly significant positive correlations were found between reading, writing, and speaking self-efficacy and MIs. The implication of this study is that with the integration of intelligences into EFL lessons, there will be a positive effect on self-efficacy in English Language Learning. Koura and AlHebaishi (2014) examined the relationship of MI, self-efficacy and academic achievement of Saudi gifted and regular intermediate students and found positive and statistically significant correlations between them.

To sum up, it can be concluded that if students are respected for their multiple intelligences, then their sense of selfefficacy is likely to increase; including multiple intelligences in the classroom teaching and learning will empower all students and ignite their sense of responsibility and efficacy as learners. In addition, by implementing and incorporating the multiple intelligences into the curricula, educators will directly support their students' individual needs and potentially open a world of possibilities to diverse learners. 


\section{Methodology:}

\section{Sampling:}

Purposive sampling is used when the researcher targets a group of people believed to be typical or average, or a group of people specially picked for some unique purpose. Since the study targeted visually impaired pupils at the preparatory stage, purposive sampling method was adopted to select participants of the current study.

\section{Participants:}

Participants of the study were seven first year preparatory stage pupils at Al-Nour school for the visually-impaired in Mansoura. Pupils' age ranged between thirteen and fourteen years old. Five of them were visually-impaired since birth, while two of them suffer from severe low vision. They had the same experience of learning English as a foreign language at the same school.

\section{Design of the study:}

The current study adopted the quasi-experimental design using a pretest- posttest one experimental group design to investigate the effectiveness of MI- based activities in developing the speaking skills and self-efficacy of VI preparatory stage pupils.

\section{Instruments:}

Three instruments were used in the current study: (available with the researcher upon request)

(1) The Multiple Intelligences Checklist:

\section{Description of the checklist:}

It is a checklist developed by Armstrong (2009, pp. 35-38) for teachers to assess their students' multiple intelligences. The checklist was adapted by adding A four- point Likert scaleranging from (1); strongly disagree to (4); strongly agree - to assess the multiple intelligences of the pupils participating in the study. It included eighty statements assessing eight types of intelligences; ten statements for each intelligence.

\section{Objective of the checklist:}

The main objective behind using the checklist was to determine the most prevailing types of intelligences among the VI pupils participating in the current study in order to design MIbased activities that match pupils' most common intelligences. 


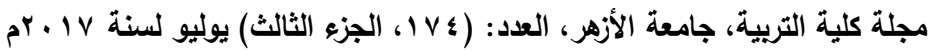

The researcher applied the Arabic version of the checklist orally to each pupil individually for the matter of feasibility and clarifying any ambiguities concerning the statements of the checklist.

\section{Application of the checklist:}

The checklist was applied orally in Arabic to each of the seven participants individually at the very beginning of the study. Results of the checklist are illustrated in the following table:

Table (1): Descriptive Statistics of the Multiple Intelligences among VI Pupils

\begin{tabular}{cccccccc}
\hline MIs & N & Minimum & Maximum & Sum & Mean & Std. D & Rank \\
\hline Verbal & 7 & $\mathbf{3}$ & $\mathbf{3 0}$ & $\mathbf{1 6 7}$ & $\mathbf{2 3 . 8 6}$ & $\mathbf{9 . 3 3 5}$ & $\mathbf{5}$ \\
Logical & 7 & $\mathbf{2 1}$ & $\mathbf{3 1}$ & $\mathbf{2 0 0}$ & $\mathbf{2 8 . 5 7}$ & $\mathbf{3 . 5 9 8}$ & $\mathbf{2}$ \\
Musical & $\mathbf{7}$ & $\mathbf{1 9}$ & $\mathbf{3 6}$ & $\mathbf{1 8 3}$ & $\mathbf{2 6 . 1 4}$ & $\mathbf{7 . 3 3 6}$ & $\mathbf{3}$ \\
Bodily & 7 & $\mathbf{2 3}$ & $\mathbf{2 8}$ & $\mathbf{1 7 2}$ & $\mathbf{2 4 . 5 7}$ & $\mathbf{1 . 6 1 8}$ & 4 \\
Visual & $\mathbf{7}$ & $\mathbf{1 3}$ & $\mathbf{1 6}$ & $\mathbf{1 0 3}$ & $\mathbf{1 4 . 7 1}$ & $\mathbf{1 . 6 0 4}$ & 7 \\
Interpersonal & 7 & $\mathbf{2 8}$ & $\mathbf{3 3}$ & $\mathbf{2 1 1}$ & $\mathbf{3 0 . 1 4}$ & $\mathbf{1 . 7 7 3}$ & $\mathbf{1}$ \\
Intrapersonal & 7 & $\mathbf{2 2}$ & $\mathbf{2 7}$ & $\mathbf{1 6 4}$ & $\mathbf{2 3 . 4 3}$ & $\mathbf{2 . 3 7}$ & $\mathbf{6}$ \\
Naturalistic & 7 & $\mathbf{1 2}$ & $\mathbf{1 6}$ & $\mathbf{9 9}$ & $\mathbf{1 4 . 1 4}$ & $\mathbf{1 . 7 7 3}$ & $\mathbf{8}$ \\
\hline
\end{tabular}

The results in Table (1) indicate that interpersonal intelligence $(M=30.14)$ was the leading intelligence among the visually impaired pupils participating in the study, followed by logical intelligence $(M=28.57)$, then musical intelligence $(M=$ 26.14) and bodily/ kinesthetic and linguistic intelligences $(M=$ 24.57and $M=23.86$ respectively). These were followed by a considerably less common intelligences, namely intrapersonal intelligence $(M=23.43)$, visual intelligence $(M=14.71)$, and finally comes naturalistic intelligence $(M=14.14)$. It was noteworthy that verbal/ linguistic intelligence had the highest standard deviation $(\mathrm{SD}=9.335)$, indicating a greater variation among the participants who showed tendency toward it. Further, visual, bodily and interpersonal intelligences appear to have the least standard deviations; and this is a confirmation of the homogeneity of this group concerning these intelligences.

Based on the results of the MI checklist, the interpersonal, logical and Musical intelligences were determined to be the most common intelligences among the visually impaired pupils participating in the current study. Consequently, the activities of the treatment were designed in the light of the previously 
determined intelligences. This result provides an answer for the first question of the current study.

(2) The Speaking Test:

The test was constructed in the light of the following resources:

- Reviewing previous studies concerned with speaking tests.

- The five speaking skills identified after reviewing "New Hello! English for first year preparatory stage, the first term.

The purpose of the test was to measure the actual level of the pupils' speaking skills. After reviewing "New Hello! English for preparatory stage, the first term," the identified speaking skills were included in the pre- post speaking skills test. The test included five situational questions where the interlocutor asks a pupil to answer or asks two pupils to ask each other and provide answers. Each question covers a range of the specified sub-skills. It didn't include visual elements or pictures to suite the nature of visual impairment.

\section{Test reliability:}

For estimating reliability of the speaking test, the researcher used the test/ retest method through administering the test to (10) pupils other than participants in the main study as a pilot sample and then re-administering it three weeks later. By calculating Pearson's correlation coefficient between the first and second administrations. The results were as illustrated in the following table:

Table (2) Correlation Coefficient between pilot sample pupils' scores on the two administrations of the Speaking Test

\begin{tabular}{lcl}
\hline $\begin{array}{l}\text { The total score of the } \\
\text { speaking test }\end{array}$ & Corr. Coeff. & Sig. \\
\cline { 2 - 3 } & 0.906 & 0.01 \\
\hline
\end{tabular}

Based on the results illustrated in table (2), it is clear that there is a statistically significant correlation at $(0.01)$ level between the first and second administrations of the test. Therefore, it is indicated that the test is highly reliable.

\section{Test validity}

To measure test content validity, the first version of the test was given to EFL jury $(N=4)$ to evaluate each question in terms of types of questions, difficulty level, arrangement and number of

$$
-\Lambda \mu \cdot-
$$




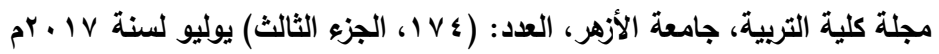

questions. The test proved to be valid as the jury approved all the questions. In addition, the calculated intrinsic validity for the speaking test was 0.90 . Therefore, the test was considered valid for the purposes of the current study.

\section{The scoring rubric of the speaking test:}

A rubric for scoring the speaking skills test was designed and attached to the test in its final version. The rubric was a holistic one since it lumped all assessment criteria together at various levels and one score is given for the entire performance or indicator. The rubric had a scale of four score points ranging as $1=$ poor, $2=$ needs improvement, $3=$ acceptable, and $4=$ distinguished. The rubric used a 4-point scale since that was believed to distinguish quality and could be easy for grading. Using an odd number of score points was avoided because of the tendency of observers to gravitate to the mean as the middle score tends to become a "dumping ground" (Arter \& McTighe, 2001: 31). The poor level was the lowest level where the pupil did not show an indication of mastering the speaking sub-skill being assessed. The second level "needs improvement" expressed pupil's performance which needed to provide an evidence of making progress toward the accepted level. The acceptable level corresponded to a level of performance where a pupil would be considered typically mastering the speaking sub-skill under observation. The distinguished level, the highest one, was established to recognize the exceptional performance of pupils who exceed the typical mastery level and who prove to have a real speaking fluency. The rubric in its initial form was presented to jurors for validation. Very few changes were made to the indicators of the rubric, and it was established in its final form.

\section{Reliability of the rubric:}

The reliability coefficient of the rubric was calculated using the inter- rater manner for the performance of the same student. The coefficient of agreement was calculated between their estimates using "Cooper" equation:

Percentage of agreement $=$ (number of times of agreement $/$ (number of times of agreement + number of times of disagreement)) $\times 100$

The researcher asked one of her colleagues to be the corater after presenting the test and its rubric and reviewing its content and instructions, by assessing the performance of three pupils- other than the participants in the main study. The agreement coefficient was calculated for each pupil. The following table shows the coefficient of agreement on the performance of the three students: 


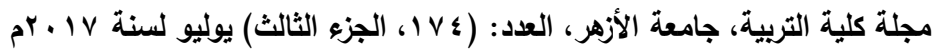

Table (3): Coefficient of Agreement on the performance of the three pupils

\begin{tabular}{|c|c|c|}
\hline $\begin{array}{l}\text { Coeff. Agree. For } 1^{\text {sh }} \\
\text { pupil }\end{array}$ & 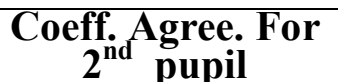 & $\underset{3^{\text {rdd }}}{\text { Coeffere. For }}$ \\
\hline
\end{tabular}

Based on statistics in the previous table, the mean coefficient of agreement between the two observers is $(88 \%)$; an indication that the rubric is highly reliable.

Results in tables (2) and (3) indicate that both the test and its rubric have a high degree of reliability, which means that they are reliable instruments for measurement.

\section{(3) The Speaking Self-Efficacy Scale:}

The speaking self-efficacy scale aimed at assessing pupils' selfefficacy level related to their performance in the speaking activities before and after implementing the proposed treatment. It consisted of twenty statements with a 4-point Likert scale type ranging from 'strongly disagree' to 'strongly agree'. Among the statements of the scale, three negative statements were included for more valid responses from the pupils.

Concerning the process of scoring the responses on the scale and recording them, it was done in the light of the alternatives provided for the pupils; strongly disagree $=1$, disagree $=2$, agree $=$ 3 , strongly agree $=4$. The negative statements were scored in the opposite direction; strongly disagree $=4$, disagree $=3$, agree $=2$, strongly agree $=1$.

\section{Content validity of the scale:}

In order to check the validity of the scale, it was presented to a group of jurors for validation and to suggest any recommended changes. Very few words were recommended to be changed and replaced with clearer ones. These suggestions were carried out and the difficult words were replaced with clearer synonyms that suite the level of the pupils. It was then ready for administration in its final form.

\section{Structural Validity (Internal consistency) of the scale:}

In order to estimate the structural validity of the scale, it was piloted to a sample of (10) pupils other than those participating in the main study. The internal consistency of the self-efficacy scale was estimated using the Cronbach's Alpha method, which is based on calculating the variance in the statements of the scale, through which the extent of correlation between the scale items/ statements to each other, and the correlation between each item with the total 
score of the scale is illustrated. It is calculated through the following equation:

$$
\alpha=\frac{N \cdot \bar{C}}{\bar{v}+(N-1) \cdot \bar{C}}
$$

Where: $\quad \mathbf{N}=$ the number of scale items.

$\overline{\mathbf{c}}=$ average covariance between item-pairs.

$\overline{\mathbf{v}}=$ average variance.

Results were as illustrated in the following table:

Table (4): Cronbach's Alpha Reliability Coefficient for the SelfEfficacy Scale

\begin{tabular}{lcc}
\hline $\begin{array}{l}\text { The self-efficacy scale as a } \\
\text { whole }\end{array}$ & No. of items & $\alpha$ coefficient \\
\cline { 2 - 3 } & 20 & 0.81 \\
\hline
\end{tabular}

Statistics in table (4) indicate that Cronbach's Alpha Reliability coefficient for the scale is $(0.81)$ which is a good value $(0.9>\alpha \geq 0.8)$. this implies that the scale is reliable and suites the purposes of the study.

Validity coefficient of the scale was calculated using the following formula:

$$
\text { Validity }=\sqrt{\text { reliability }}=\mathbf{0 . 9}
$$

This is an indication that the self-efficacy scale is highly valid and reliable.

\section{The treatment:}

\section{Aim of the treatment:}

This treatment aimed at developing the EFL speaking skills and self-efficacy of visually impaired pupils at the preparatory stage. To achieve that aim, speaking activities based on the multiple intelligences theory (MIT) were designed and implemented in the EFL classroom.

\section{Objectives of the treatment:} to:

By the end of the proposed treatment, pupils should be able

1. Follow spoken grammatical rules correctly (such as subject/verb agreement, word order within utterances, and correct use of tenses, articles and voice). 


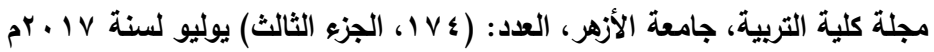

2. Use a relevant, adequate and appropriate range of vocabulary

3. Demonstrate intelligible pronunciation

4. Speak fluently adopting a reasonable rate of speech

5. Comprehend conversations, and consequently their answers are comprehensive and expressive

\section{Content and duration of the treatment:}

The treatment was applied during the first term of the academic year 2016/2017. The content was divided into 12 sessions, each session lasted for forty five minutes in addition to two sessions for the pre- and post-administrations of the instruments of the study. During each session the pupils practised the predetermined speaking sub-skills through the designed activities. These activities were based on the three most dominating intelligences, i.e. interpersonal, logical and musical intelligences, identified through the multiple intelligences checklist.

Proposed activities were based on the objectives of the lesson, functions to be mastered in each lesson, the specified dominant intelligences, and the content of each lesson. The speaking activities that represent interpersonal intelligence included role- play, interviewing others, participating in simulations, working cooperatively, chatting, joint storytelling, and discussions. In addition, logical intelligence activities included solving or creating problems and logic puzzles, prediction, classifying, brainstorming, and creating rational arguments. Finally, musical intelligence activities included songs, playful learning, and brainstorming using rhythms or tunes as analogies.

The activities were applied throughout the whole lesson whenever possible; including warm-up activities, pre-task activities, and post-task activities.

Various instructional aids and supplementary materials were used in accordance with the proposed activities. Audio materials such as short stories and songs were made use of. In addition, handouts in Braille and tactile models were also used.

\section{Evaluation:}

The evaluation integrated in the treatment composed of both formative and summative evaluation. Formative evaluation aimed at assessing learners' gradual progress in speaking through regular procedures such as asking questions or getting pupils to role play a conversation. Necessary feedback on the pupils' overall speaking performance was provided at the end of each lesson. 
The second type of evaluation was summative. This was conducted at the end of the treatment implementation. It included the administration of the EFL speaking skills posttest. Its purpose was to measure the actualization of the intended goals at the end of the treatment application. Namely; it aimed at investigating the effectiveness of the proposed MI-based activities in developing first year preparatory stage visually impaired pupils' speaking sub-skills and self-efficacy.

\section{Results and Discussion:}

\section{Results:}

The results of the study will be presented in terms of the study hypotheses as follows:

Hypothesis one: "There is a statistically significant difference at (0.05) level between the mean ranks of the experimental group pupils' scores on the pre- and postadministrations of the speaking test in favor of the postadministration".

In order to test the previous hypothesis, the researcher used "Wilcoxon Test" for related groups in the case of nonparametric statistics (as the sample of the study consisted of seven participants $(\mathrm{N}=7<30)$. The following table illustrates $(\mathrm{Z})$ values and their statistical significance for the differences between the pupils' scores on the speaking rubric at the pre- and post administrations of the speaking skills test.

Table (5): The value of (Z) and its statistical significance of the difference between pre-and post-administrations of speaking test to the experimental group

\begin{tabular}{ccccccc}
\hline Skills & Ranks & N & $\begin{array}{c}\text { Mean } \\
\text { Rank }\end{array}$ & $\begin{array}{c}\text { Sum } \\
\text { of } \\
\text { Ranks }\end{array}$ & $\begin{array}{c}\text { Z } \\
\text { Value }\end{array}$ & Sig \\
\hline \multirow{2}{*}{ pronunciation } & $\begin{array}{c}\text { Negative } \\
\text { Ranks }\end{array}$ & 0 & 0 & 0 & & \\
\cline { 2 - 5 } & $\begin{array}{c}\text { Positive } \\
\text { Ranks }\end{array}$ & 7 & 4 & 28 & 2.53 & 0.05 \\
\cline { 2 - 6 } grammar & $\begin{array}{c}\text { Ties } \\
\text { Negative } \\
\text { Ranks }\end{array}$ & 0 & 0 & 0 & 2.428 & 0.05 \\
\cline { 2 - 6 } & $\begin{array}{c}\text { Positive } \\
\text { Ranks }\end{array}$ & 7 & 4 & 28 & & \\
\hline
\end{tabular}




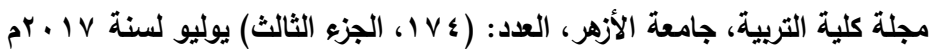

\begin{tabular}{|c|c|c|c|c|c|c|}
\hline Skills & Ranks & $\mathbf{N}$ & $\begin{array}{l}\text { Mean } \\
\text { Rank }\end{array}$ & $\begin{array}{c}\text { Sum } \\
\text { of } \\
\text { Ranks }\end{array}$ & $\begin{array}{c}Z \\
\text { Value }\end{array}$ & Sig \\
\hline & Ties & 2 & -- & -- & & \\
\hline \multirow{3}{*}{ vocabulary } & $\begin{array}{c}\text { Negative } \\
\text { Ranks }\end{array}$ & $\mathbf{0}$ & $\mathbf{0}$ & $\mathbf{0}$ & \multirow{3}{*}{2.46} & \multirow{3}{*}{0.05} \\
\hline & $\begin{array}{c}\text { Positive } \\
\text { Ranks }\end{array}$ & 7 & 4 & 28 & & \\
\hline & Ties & $\mathbf{0}$ & $\overline{--}$ & -- & & \\
\hline \multirow{3}{*}{ fluency } & $\begin{array}{c}\text { Negative } \\
\text { Ranks }\end{array}$ & $\mathbf{0}$ & $\mathbf{0}$ & $\mathbf{0}$ & \multirow{3}{*}{2.07} & \multirow{3}{*}{0.05} \\
\hline & $\begin{array}{c}\text { Positive } \\
\text { Ranks }\end{array}$ & 5 & 3 & 15 & & \\
\hline & Ties & 2 & -- & -- & & \\
\hline \multirow{3}{*}{ Comprehensibility } & $\begin{array}{c}\text { Negative } \\
\text { Ranks }\end{array}$ & $\mathbf{0}$ & $\mathbf{0}$ & $\mathbf{0}$ & \multirow{3}{*}{2.428} & \multirow{3}{*}{0.05} \\
\hline & $\begin{array}{c}\text { Positive } \\
\text { Ranks }\end{array}$ & 7 & 4 & 28 & & \\
\hline & Ties & $\overline{\mathbf{0}}$ & $\overline{--}$ & $\overline{--}$ & & \\
\hline \multirow{3}{*}{ Total } & $\begin{array}{l}\text { Negative } \\
\text { Ranks }\end{array}$ & $\mathbf{0}$ & $\mathbf{0}$ & $\mathbf{0}$ & \multirow{3}{*}{2.388} & \multirow{3}{*}{0.05} \\
\hline & $\begin{array}{c}\text { Positive } \\
\text { Ranks }\end{array}$ & 7 & 4 & 28 & & \\
\hline & Ties & $\overline{0}$ & $\overline{--}$ & -- & & \\
\hline
\end{tabular}

It is clear that the values of " $Z$ " were statistically significant at $(0.05)$ level of significance in favor of the postadministration of the speaking test, both for the total score of the test and the scores of the comprised sub-skills. This indicates that there is a significant difference between the mean ranks of the experimental group pupils' scores on the pre- and postadministrations of the speaking skills test in favor the postadministration. Thus, the first hypothesis was accepted.

The previously obtained results concerning the statistical differences between the pre- and post- administrations of the speaking test, both the constituting sub-skills and the total score of the test on the scoring rubric can be illustrated though the following figure: 


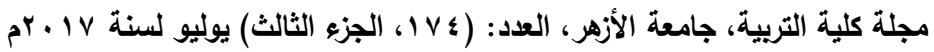

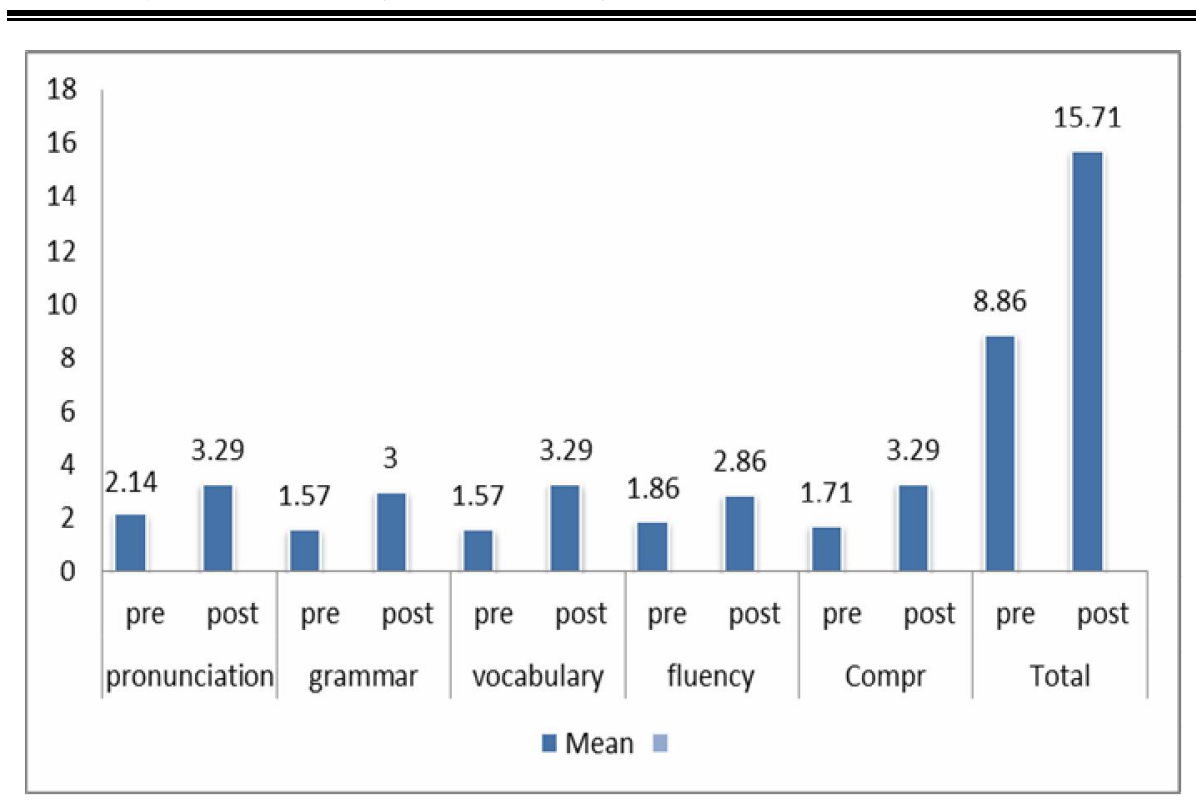

Figure (2): Differences between pre-and post-administrations of speaking test to the experimental group

To verify the contribution of the proposed treatment; i.e. MI- based activities to developing EFL speaking skills for the visually impaired, the effect size of the proposed treatment was estimated through comparing the mean ranks of experimental group pupils' scores on the pre- and post-administrations of the speaking test using McGogian's gain ratio.

McGugian Gain Ratio $=(\mathbf{Y}-\mathbf{X}) /(\mathbf{P}-\mathbf{X})$

Where: $\quad \mathrm{Y}=$ average of post-test grade,

$X=$ average of pre-test grade,

$P=$ test max.

Table (6): The Effect Size of MI- Based Activities in Developing EFL speaking skills of VI preparatory stage pupils

\begin{tabular}{rrr}
\hline & Skills & \\
\hline \multirow{3}{*}{ grammar } & pronunciation & Effectiveness \\
\cline { 3 - 3 } & vocabulary & $\mathbf{5 9 \%}$ \\
\cline { 3 - 3 } & fluency & $\mathbf{7 0 . 7 8 \%}$ \\
\cline { 3 - 3 } & Comprehensibility & $\mathbf{4 6 . 7 \%}$ \\
\cline { 3 - 3 } & Total & $\mathbf{6 9 \%}$ \\
\cline { 3 - 3 } & & $\mathbf{6 1 . 5 \%}$ \\
\hline
\end{tabular}

Statistics in table (6) illustrate that the effect size of the proposed treatment on the speaking skill as a whole was $(61.5 \%)$, 
which is an acceptable ratio according to McGogian equation where the effect ratio should equal or surpass a percentage of $(60 \%)$. These statistics can be interpreted that $(61.5 \%)$ of variance in performance of the pupils' speaking skills as a whole can be attributed to the implementation of the proposed treatment. Concerning speaking subskills, the effect ratio ranged between $(46.7 \%$ and $70.78 \%)$ which is considered an acceptable effect according to McGogian. An interpretation for these statistics can be provided that a percentage that ranged between $46.7 \%$ and $\mathbf{7 0 . 7 8 \%}$ of variance in pupils' performance in relation to their speaking subskills can be attributed to the effect of implementing the proposed MI- based activities. It is noticed that pupils' fluency is the least to be affected by the treatment. This can be attributed to the considerably low verbal/ linguistic intelligence those pupils have; a major factor that contributes to language development and fluency in language use.

Hypothesis two: "There is a statistically significant difference at (0.05) level between the mean ranks of the experimental group pupils' scores on the pre- and postadministrations of the self-efficacy scale in favor of the postadministration".

To verify this hypothesis, the researcher used "Wilcoxon Test" for related groups in the case of non-parametric statistics (as the sample of the study consisted of seven participants $(\mathrm{N}=7<$ $30)$ ). The following table illustrates $(Z)$ values and their statistical significance for the differences between the pupils' scores on preand post -administrations of the speaking self-efficacy scale.

Table (7): The value of $(Z)$ and its significance for the difference between the pre-and post-administrations of speaking self-efficacy scale

\begin{tabular}{llccccc}
\hline \multirow{2}{*}{ Total } & Ranks & N & $\begin{array}{l}\text { Mean } \\
\text { Rank }\end{array}$ & $\begin{array}{c}\text { Sum of } \\
\text { Ranks }\end{array}$ & $\begin{array}{c}\text { Z } \\
\text { Value }\end{array}$ & Sig \\
\cline { 2 - 7 } & $\begin{array}{l}\text { Negative } \\
\text { Ranks } \\
\text { Positive }\end{array}$ & 0 & 0 & 0 & & \\
$\begin{array}{l}\text { Ranks } \\
\text { Ties }\end{array}$ & 7 & 4 & 28 & 2.392 & 0.05 \\
\hline
\end{tabular}
significant at $(0.05)$ level of significance in favor of the postadministration of the speaking self- efficacy scale. This indicates that there is a significant difference between the mean ranks of the experimental group pupils' scores on the pre- and post- 


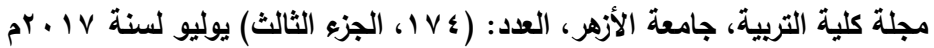

administrations of the speaking self- efficacy scale in favor the post-administration. Thus, the second hypothesis was accepted.

The previously obtained results concerning the statistical differences between the pre- and post- administrations of the speaking self-efficacy scale can be illustrated though the following figure:

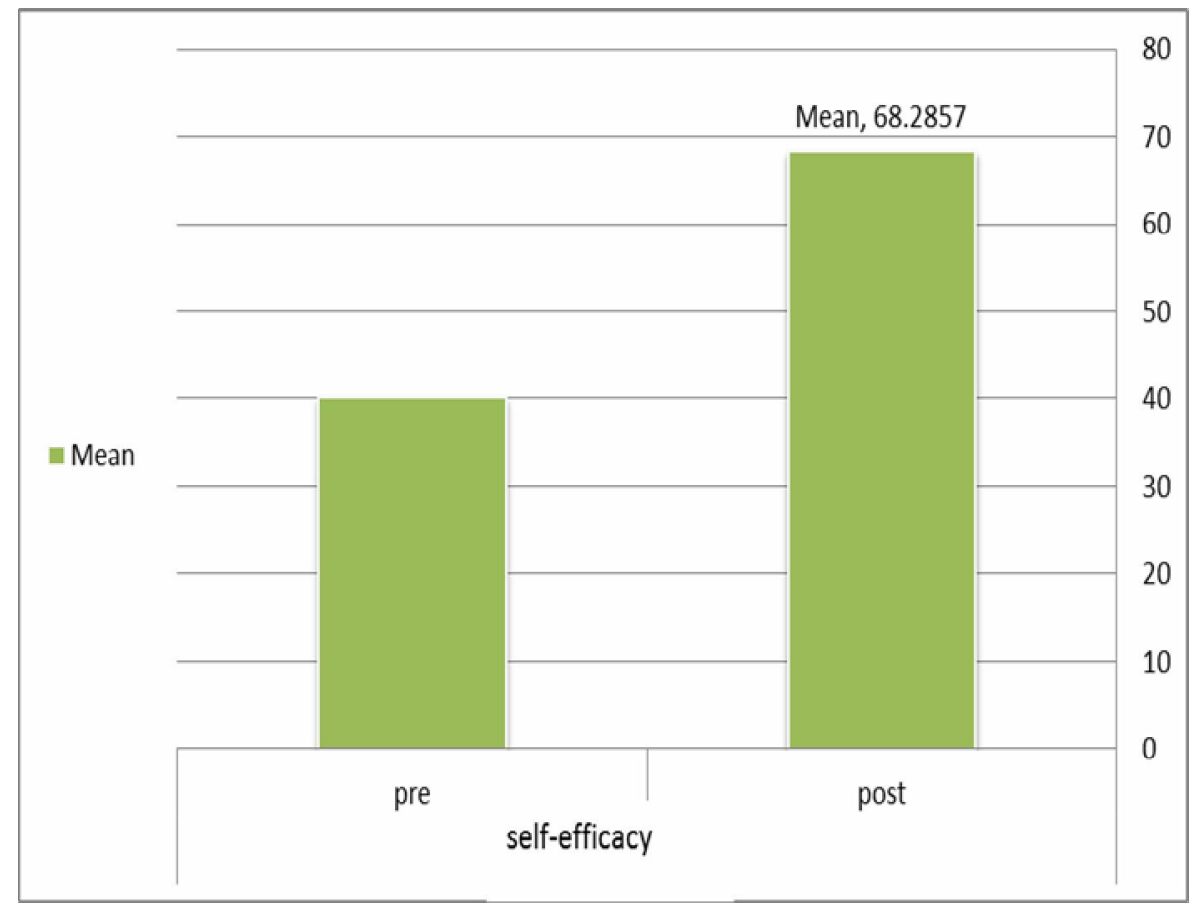

Figure (3): Difference between pre-and post-administrations of Speaking Self-Efficacy Scale to the experimental group

To verify the contribution of the proposed treatment; i.e. MI- based activities to improving EFL speaking self-efficacy beliefs for the visually impaired, the effect size of the proposed treatment was estimated through comparing the mean ranks of experimental group pupils on the pre- and post-administrations of the speaking self-efficacy scale using McGogian's gain ratio. Results were as follows:

Table (8): The effect size of MI-Based Activities in developing EFL speaking self-efficacy

\begin{tabular}{c}
\hline Total \\
\cline { 2 - 2 }$-\wedge \% q-$
\end{tabular}




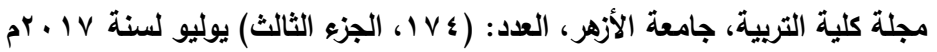

Statistics in table (8) illustrate that the effect size of the proposed treatment on the speaking self-efficacy beliefs was (70.6\%), which is a high ratio according to McGogian equation where the effect ratio should equal or surpass a percentage of $(60 \%)$. These statistics can be interpreted that $(\mathbf{7 0 . 6 \%})$ of improvement in the pupils' speaking self-efficacy beliefs can be attributed to the implementation of the proposed treatment.

\section{Discussion:}

The current study attempted to investigate the effectiveness of implementing MI- based activities for developing EFL speaking skills and self-efficacy of visually impaired pupils at the preparatory stage. The results revealed a statistically significant difference between the mean ranks of the experimental group pupils' scores on the pre- and post- administrations of the speaking test in favor of the post- administration. The difference is apparent in both the total score of the test and the scores of the sub-skills combined in the speaking test. This means that visually impaired pupils' speaking skills improved as a result of applying the proposed MI-based activities in the EFL Classroom.

The present study provides evidence for the effectiveness of using MI- based activities in developing first year preparatory stage pupils' EFL speaking skills and its constituent subskills. It is consistent with the results of similar studies (Ibrahim, 2007; Dorgham, 2011). The reached results could be attributed to the interesting nature of MI- based activities that addressed pupils' strengths and areas of interest. The varied nature of the proposed activities also created an enjoyable atmosphere in the classroom, away from the daily routine of traditional practices in the EFL lessons. However, the activities did not address pupils' areas of weakness; namely verbal/ linguistic intelligence which could be an essential factor in language skills development, specially fluency in speaking. It was the current study's scope of interest to focus on the most common types of intelligences among VI pupils participating in the study.

Further, it proved that there was a statistically significant difference at $(0.05)$ level between the mean ranks of the experimental group pupils' scores on the pre- and postadministrations of the speaking self-efficacy scale in favor of the post- administration.

The results of this study related to speaking self-efficacy are consistent with those of previous studies such as Shore (2001, cited in Al-Faoury \& Smadi, 2015) and Koura and Al-Hebaishi (2014) . This result could be interpreted in the light of successful experiences that pupils had during performing EFL speaking MI- 


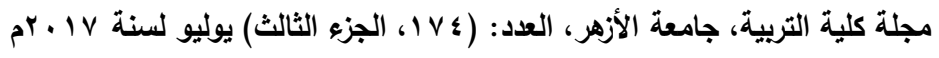

based activities. It is acknowledged that self- efficacy beliefs improve when students experience success in relation to certain tasks (Bandura, 1994). Being relevant to pupils' areas of strength, these MI- based activities inevitably would be a source of successful experiences for VI pupils.

Generally, pupils who participated in the study expressed their satisfaction with the activities; they found them different, encouraging, interesting, and sometimes challenging to a degree that ignited their motivation to succeed and achieve their goals.

They were satisfied with their performance during the experiment as they felt successful, cooperative and supportive for each other; and this highlights the prominent interpersonal intelligence among them.

\section{Conclusions:}

The current study aimed at investigating the effectiveness of integrating MI- based activities in EFL classes in developing the speaking skills and self-efficacy beliefs of visually impaired pupils at the preparatory stage. The results demonstrated a significant difference between the pre- and post- administrations of the speaking test and the self-efficacy scale; tools of the study. This implies that the proposed MI-based activities were effective in developing EFL speaking skills and enhancing the self-efficacy beliefs of first year prep stage visually impaired pupils.

The findings of the current study suggest that EFL teachers of the visually impaired should be creative and try hard to provide an instructional environment that is supportive and encouraging for those pupils; such an environment that builds upon their strengths and extend to polish their skills and strengthen their positive beliefs about themselves.

The findings also suggest that Multiple Intelligences theory is a rich source of implications that can be employed in the EFL classroom for developing speaking skills and enhancing selfefficacy beliefs of the visually impaired; a factor that contributes greatly to the success of pupils in task performance.

\section{Recommendations:}

In the light of the results of the current study the following recommendations are suggested:

- Special education curriculum designers should pay adequate attention towards the necessity of adapting VI EFL textbooks to suit their visual impairment and exploit their remain senses and their multiple intelligences. 
- EFL curriculum planners should pay sufficient attention towards the importance of integrating MI theory in EFL textbooks, especially for the VI pupils.

- EFL teachers of the VI should adapt their teaching practices to suit the needs of their pupils through implementing MI-based activities in their classes to develop several language skills.

- Researchers in the field of EFL for special education in general and for VI pupils in particular, should exert tremendous efforts for tackling the language issues related to this field; as this field is currently, although very important, still under- researched.

\section{Suggestions for further research:}

In the light of results and recommendations proposed by the current study, the following research topics are suggested:

- The effectiveness of MI- based activities in developing EFL listening skills of the visually impaired pupils at different educational stages (primary, preparatory, secondary).

- The effect of implementing MI- based E- activities in developing EFL reading comprehension and decreasing cognitive load for visually impaired pupils at the preparatory stage.

- The effectiveness of using verbal/ linguistic-based enrichment activities for developing some EFL language skills for the visually impaired pupils at the preparatory stage. 


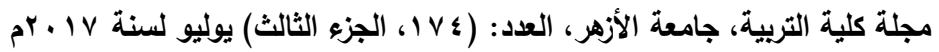

\section{References}

Ainy, S. (2007). Use of Literature in Developing Learners' Speaking Skills in Bangladeshi EFL Contexts. A Ph.D. Thesis, University of Nottingham.

Al-Faoury, O.\& Smadi, O. (2015). The Effect of an Integrative Skills Program on Developing Jordanian University Students' Select Multiple Intelligences. Theory and Practice in Language Studies, 5 (1), 38-48.

Armstrong, T. (2000). Multiple Intelligences in the Classroom, $2^{\text {nd }}$ ed. Alexandria: Virgenia.

Armstrong, T. (2009). Multiple Intelligences in the classroom, $3^{\text {rd }}$ ed. ASCD: Alexandria, Virginia USA.

Arnold, J.\& Fonseca, C. (2004). Multiple Intelligence Theory and Foreign Language Learning: A Brain-based Perspective, International Journal of English Studies, IJES, 4 (l), 119-136.

Arter, J. \& McTighe, J. (2001). Scoring Rubrics in the Classroom. California: Corwin Press, Inc.

Asakereh, A. \& Dehghannezhad, M. (2015). Student satisfaction with EFL speaking classes: Relating speaking self-efficacy and skills achievement. Issues in Educational Research, 25(4), 345- 363.

Bandura, A. (1994). Self-efficacy. In V. S. Ramachaudran (Ed.), Encyclopedia of human behavior , 4, 71-81. New York: Academic Press.

Başaran, S. (2012). Teaching English to visually impaired students in Turkey: A case study. Energy Education Science and Technology Part B: Social and Educational Studies, Special Issue 2: 217-226.

Boonkit, K. (2010). Enhancing the development of Speaking Skills for Non- native Speakers of English. Procedia Social and Behavioral Sciences, 2, 1305- 1309.

Brown, H. (1994). Teaching by principles: An Interactive Approach to Language Pedagogy. Englewood Cliffs, NJ: Prentice Hall Regents.

Brown, H. (2004). Language Assessment Principles: An Interactive Approach to Language Pedagogy. San Francisco, CA: Longman.

Burns, A.\& Joyce, H. (1997). Focus on Speaking. Sydney: National Center for English Language Teaching and Research. 


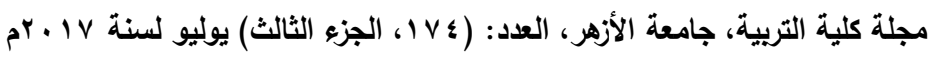

Bygate, M. (2001). Speaking. In Roland Carter and David Nunan (Eds), Teaching English to Speakers of Other Languages. Cambridge: Cambridge University Press.

Chea, S.\& Shumow, L. (2014). The Relationships Among Writing Self-Efficacy, Writing Goal Orientation, and Writing Achievement. Language Education in Asia, 5 (2), 253-269.

Chen, H. (2007). The relationship between EFL learners' selfefficacy beliefs and English performance. Ph.D. thesis, Florida State University.

Christidou, S. (2016). Foreign Language Learning for the Visually Impaired in the Region of Central Macedonia, Greece: Problems and Suggestions. US-China Foreign Language, 14 (3), 214-226.

Christison, M.A. (1999). A guidebook for Applying Multiple Intelligences Theory in the ESL/EFL Classroom. Burlingame, CA: Alta Book Center.

Coşkun, A. (2013). English language teaching for the visually impaired learners: Training non-native English teachers. International Journal of Social Sciences \& Education, 4(1), 289-295.

Cubukcu, F. (2008). A Study of the Correlation between Self Efficacy and Foreign Language Learning Anxiety. Journal of Theory and Practice in Education, 4 (1), 148- 158.

Davis, P. (2003). Including Children with Visual Impairment to the Mainstream Schools. London: David Fulton Publishers.

Davoudi, M. \& Chavosh, M. (2016). The Relationship between Multiple Intelligences and Listening Self-Efficacy among Iranian EFL Learners. English Language Teaching, 9 (6), 199- 212.

Derakhshan, A. \& Faribi, M. (2015). Multiple Intelligences: Language Learning and Teaching. International Journal of English Linguistics, 5 (4), 63- 72.

Diyyab, E. (2013). Using a Multimedia- Based Program for Developing Student Teachers' EFL Speaking Fluency Skills. Faculty of Education, Benha University.

Dorgham, R. (2011). The effectiveness of a proposed program in developing the speaking skills of English language among preparatory stage pupils in the light of multiple intelligences theory. PhD thesis. Institute of Educational Studies. Cairo University. 


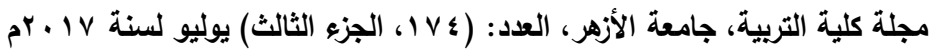

Efstathiou, A.\& Polichronopoulou, S. (2015). Teaching English as a Foreign Language to Visually Impaired Students: Teaching Materials Used by Teachers of English, In G. Kouroupetroglou (Ed.), Proceedings of ICEAPVI, 12-14 February, Athens, Greece.

El-Embaby, A. (2008). EFL students Writing Competencies and Determine the Effectiveness of Multiple Intelligences. Retrieved on December, 2016, from www.foe.zu.edu.eg/Heigher\%20studies.htm

Eng, L.\& Mustapha, G. (2010). Enhancing writing ability through multiple intelligences strategies. Pertanika Journal of Sociology, Science, \& Humanities, 18, 53-63.

Farag, M. (2015). Utilizing a Computer Mediated Program in Developing EFL Primary Stage Pupils' Speaking Skills and Motivation. M.A. Thesis, Faculty of Education, Mansoura University.

Galetová, I. (2012). Lesson Planning for Visually Impaired Students of English, M.A. Thesis, Masaryk University, The Faculty of Pedagogy, Czech Republic.

Gardner, H (1983). Frames of Mind: The Theory of Multiple Intelligences, Basic Books, New York, USA.

Gardner, H. (1999). Intelligence reframed: Multiple Intelligences for the $21^{\text {st }}$ Century. Basic Books, New York: USA.

Grow, G. (1990). Writing and multiple intelligences. Retrieved from ERIC Database Document Reproduction Services (ED 406 643).

Gullatt, D. (2008). Enhancing Student Learning Through Arts Integration: Implications for the profession. The High School Journal, April/ May, 12-25.

Habibi, A. \& Jamila, A. (2014). Teachers' Strategies In Teaching English To Visually impaired Students. A paper presented at Sriwijaya University Learning and EducationInternational Conference, Faculty of Teacher Training and Education, Sriwijaya University, Palembang, May 16-18, 2014.

Hajhashemi, K., Akef, K. \& Anderson, N. (2012). The Relationship between Multiple Intelligences and Reading Proficiency of Iranian EFL Students. World Applied Sciences Journal, 19(10), 1475-1483. 


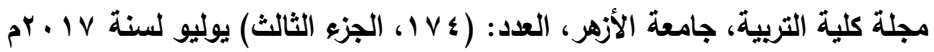

Hallahan, D. P., \& Kauffman, J. M. (1991). Exceptional children: Introduction to Special Education (5th ed.). United States of America: Prentice-Hall International Inc.

Hanafiyeh, M. (2013). On the Relationship between Iranian EFL Learners Multiple Intelligence and Success in Foreign Language Learning. Asian Journal of Management Sciences and Education, 2(1), 97-105.

Hedges, J.\& Gable, R. (2016). The Relationship of Reading Motivation and Self-Efficacy to Reading Achievement. $K$ 12 Education. $\quad$ Paper 31. http://scholarsarchive.jwu.edu/k12_ed/31

Hosseini Fatemi, A. \& Vahidnia, F. (2013). An investigation into Iranian EFL learners' level of writing self-efficacy. Theory and Practice in Language Studies, 3(9), 1698-1704.

Ibnian, S.\& Hadban, A. (2013). Implications of Multiple Intelligences Theory in ELT Field. International Journal of Humanities and Social Science, 3 (4) [Special Issue February 2013].

Ibrahim, A. (2007). The Effectiveness of a Suggested Teaching Strategy Based on Multiple Intelligences Theory on Developing Third Year Primary School Pupils' Speaking Skills. MA Thesis. Institute of Educational Studies. Cairo University.

Jayakody, A., Lokuliyana, S., Sampath, A., Silva, G., Rajanthika, S. \& Seneviratne, H. (2016). Mobile application for vision impaired people to facilitate to learn the English language. International Journal of Computer Applications, 138 (12), 12-17.

Kargar, M. \& Zamanian, M. (2014). The relationship between self-efficacy and reading comprehension strategies used by Iranian male and female EFL learners. International Journal of Language Learning and Applied Linguistics World, 7(2), 313-325.

Kashdan, S., Barnes, R. \& Walsh, C. (2002). Teaching English as a new language to visually impaired and blind ESL students: Problems and possibilities. Paper presented at A Celebration of Solutions. National Symposium on Literacy for Adults with Visual Disabilities, Atlanta, Georgia, September 20, 2002. Retrieved from http://www.afb.org/info/literacyinstructors/nationalsympo siumon-literacy/teaching-english-as-a-new-language/345 


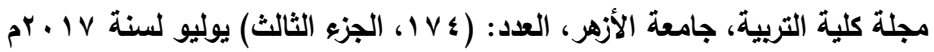

Khatib, F.\& Marouf, N. (2015). Self-efficacy perception of oral communication ability among English as a Second Language (ESL) Technical Students, Procedia - Social and Behavioral Sciences, 204, 98 - 104. Available online at www.sciencedirect.com

Koura, A. \& Al-Hebaishi, S. (2014). The Relationship between Multiple Intelligences, Self-Efficacy and Academic Achievement of Saudi Gifted and Regular Intermediate Students, Educational Research International, 3(1), 48- 70.

Liu, M. (2013). English Bar as a venue to boost students' speaking self -efficacy at the tertiary level. English Language Teaching, 6(12), 27.

Lovi, M. (2013). Aspects Of Teaching And Learning English As A Foreign Language In The Case Of Blind And Visually Impaired Learners In Estonia, M.A. Thesis, University Of Tartu, Estonia.

Marefat, F. (2007). Multiple intelligence: Voices from an EFL writing class. Pazhuhesh-e Zabanha-ye Khareji, 32(Special Issue in English), 145-162.

McKenzie, W. (2002). Multiple intelligences and instructional technology: A manual for every mind. Eugene, OR: International Society for Technology in Education.

McMahon, S., Rose, D., \& Parks, M. (2004). Multiple intelligences and reading achievement: An examination of the Teele Inventory of multiple intelligences. The Journal of Experimental Education, 73(1), 41- 52.

Milian, M. \& Pearson, V. (2005). Students with visual impairments in a dual-language program: A case study. Journal of Visual Impairment \& Blindness (JVIB), 99(11), 1-13.

Modirkhamene, S. \& Azhiri, M. (2012). The Effect of Multiple Intelligences-based Reading Tasks on EFL Learners' Reading Comprehension. Theory and Practice in Language Studies, 2 (5),1013-1021.

Mohamed, D. (2004). The Effectiveness of a Program Based on Cooperative Learning for Visually Impaired Students at the Primary Stage on Developing their English Vocabulary. Unpublished M.A. Thesis, Faculty of Education, Ain Shams University. 


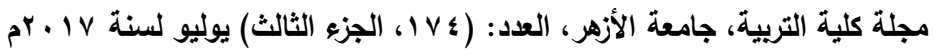

Mohammed, R. (2004). The Effectiveness of a Program Using Creative Dramatics in Developing the communicative Listening Comprehension and Speaking Skills of Egyptian Elementary Fourth Grades Learning English. Faculty of Education, Minia University.

Mushome, A.\& Monobe, R. (2013). The Attitude of Lecturers Towards Visually Impaired Students: A Case Study of One of the Universities in the Limpopo Province in South Africa. US-China Education Review A, 3 (2), 108-113. ED 540480.

Naseri, M. \& Zaferanieh, E. (2012). The relationship between reading self- efficacy beliefs, reading strategy use and reading comprehension level of Iranian EFL learners. World Journal of Education, 2 (2), 64-75.

Nunan, D. (2003). Practical English Language Teaching. Singapore: McGraw Hill.

Oradee, T. (2012). Developing Speaking Skills Using Three Communicative Activities. International Journal of Social Science and Humanity, 2 (6): 533-535

Pajares, F. (2000). Current directions in self-efficacy research. In M. Maehr \& P. R. Pintrich (Eds.), Advances in Motivation and Achievement, Volume 10, (pp. 1-49). Greenwich, CT: JAI Press.

Pajares, F., \& Johnson, M. J. (1996). Self-efficacy beliefs and the writing performance of entering high school students. Psychology in the Schools, 33(2), 163-175.

Pajares, F., \& Valiante, G. (1997). Influence of self-efficacy on elementary students' writing. The Journal of Educational Research, 90(6), 353-360.

Priyadarshini, S. (2015). Multiple Intelligence among Low Vision Children - An Analysis. Educational Quest: An Int. J. of Education and Applied Social Sciences, 6 (2).

Quatraro, A. (2011). ELLVIS - English Language Learning for Visually Impaired Students, final project report. Italy, Italian Union of the Blind provincial section of Florence.

Rahimi, A. \& Abedini, A. (2009). The interface between EFL learners' self -efficacy concerning listening comprehension and listening proficiency. Novitas ROYAL, 3(1): 14-28. http://www.novitasroyal.org/Vol_3_1/rahimi_abedini.pdf 


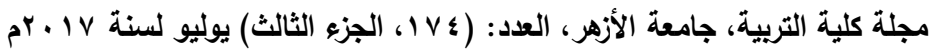

Razmjoo, S. (2008). On The Relationship Between Multiple Intelligences And Language Proficiency. The Reading Matrix, 8 (2), 155- 174.

Richards, J. C. (2008). Teaching Listening and Speaking: from Theory to Practice. New York: Cambridge University Press.

Richards, J.\& Rodgers, T. (2001). Approaches and Methods in Language Teaching. $2^{\text {nd }}$ ed. Cambridge: Cambridge University Press.

Richards, J.C. \& Renandya, W. (2002). Methodology in Language Teaching. Cambridge: Cambridge University Press.

Salem, A. (2013). The impact of multiple intelligences- based instruction on developing speaking skills of the pre- service teachers of English. English Language Teaching, 6(9): 5366.

Salisbury, R. (Ed.) (2008). Teaching Pupils with Visual Impairment: A guide to making the school curriculum accessible. NY: Routledge.

Shang, H. (2011). Exploring the relationship between EFL proficiency level and reading strategy use. International Journal of Hum anities and Social Science, 3: 18-27.

Shumin, K. (2002). Factors to consider: Developing Adult EFL Students' speaking abilities. In J. Richards\& W. Renandya (Eds): Methodology in Language Teaching. Cambridge: Cambridge University Press. Pp. 204- 211.

Stein, V., Nebelrath, R., Alexandersson, J., \& Tröger, J. (2011). Designing with and for the visually impaired: vocabulary, spelling and the screen reader. Paper presented at International Conference on Computer Supported Education (CSEDU-11), Noordwijkerhout, Netherlands (462-467).

Torky, S. (2006). The Effectiveness of a Task- Based Instruction program in Developing the English Language Speaking Skills of Secondary Stage Students. Ph.D. Thesis, Women's College, Ain Shams University.

Tumova, M. (2002). Speaking Activities Aimed at Developing Fluency in EFL Classes. M.A. Thesis, Faculty of Humanities, Pardubice University.

Ur, P. (2009). A Course in Language Teaching: Practice and Theory. Cambridge: Cambridge University Press. 
Yogurtcu, K. (2013). The impact of self-efficacy perception on reading comprehension on academic achievement. Procedia - Social and Behavioral Sciences, 70: 375 - 386.

Zhu, H. (2011). The Application of Multiple Intelligences Theory in Task-based Language Teaching. Theory and Practice in Language Studies, 1 (4): 408-412.

Zimmerman, B. J. (2000). Self-Efficacy: An Essential Motive to learn. Contemporary Educational Psychology, 25: 82-91.

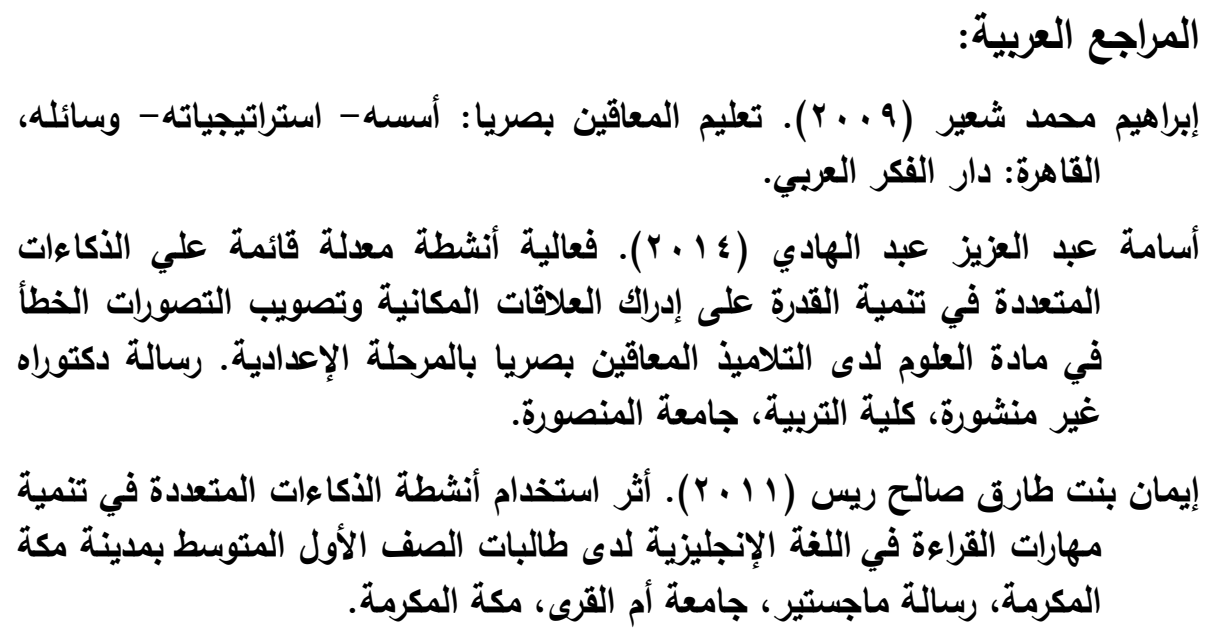

